\title{
ALIMENTARY MYCOTIC LESIONS IN CATTLE: A HISTOLOGICAL AND CULTURAL STUDY
}

\author{
K. W. Angus*, N. J. L. Gilmour* and Christine O. Dawson† \\ * Moredun Research Institute, Edinburgh and $\dagger$ Department of Pathology, \\ University of Glasgow Veterinary School
}

\section{Plates V and VI}

VARIOUS manifestations of alimentary mycosis in cattle have been recorded by several authors (Gleiser, 1953; Ainsworth and Austwick, 1955; Davis, Anderson and McCrory, 1955; Gitter and Austwick, 1957; Cordes and Shortridge, 1968) and a review of the literature on alimentary mycosis in animals was carried out by Smith (1968). Reports indicate that fungal infections of the digestive tract are generally sporadic. Austwick (1962) found miliary nodules containing " asteroid bodies " in 66 per cent. of the lungs of slaughtered dairy cows; about half of the lesions contained fungal hyphae. Recently, microscopical lesions containing asteroid bodies which enclosed hyphae of Aspergillus fumigatus were observed in the intestines and mesenteric lymphnodes in two groups of experimental calves dosed with Mycobacterium avium (Gilmour and Angus, 1969; Angus and Gilmour, 1970), but it was not known at that time whether such lesions were common in cattle kept in farm environments.

This communication describes similar lesions in apparently healthy cattle slaughtered at an abattoir and the isolation of a number of fungal species from the mesenteric lymph-nodes. The findings came to light in a survey originally designed to study the incidence of $M$. johnei infection.

\section{MATERIALS AND METHODS}

Animals. Material from 100 cattle was obtained from the municipal abattoir in Edinburgh between $1 \mathrm{Jan}$. and 31 Aug. 1971. Intestines and mesenteric lymph-nodes were collected three or four times weekly.

Histology. Two blocks of tissue, including the Peyer's patch, were taken from each of six 3-m lengths of small intestine from every animal, and one block from the mesenteric lymph-node draining each length (Gilmour, Nisbet and Brotherston, 1965). The material was fixed in 10 per cent. buffered formol-saline, with secondary fixation in formol-sublimate. Tissue was embedded in paraffin-wax and sections $5 \mu \mathrm{m}$ thick were cut and stained with celestin blue-Mayer's haematoxylin and eosin. The periodic acid-Schiff (PAS), Ziehl-Neelsen and van Gieson methods, and Perl's method for haemosiderin, were also used.

Cultural techniques. Cattle nos. 1-34 (see the table) were examined only by a routine culture method for M. johnei (Brotherston, Gilmour and Samuel, 1961). This method did not absolutely exclude the possibility of fungal contamination. Cattle nos. 35-100 were examined by a method designed specifically for the isolation of pathogenic fungi. Lymphnodes were taken from the middle of the mesenteric chain, but they were not the same as 
those sectioned for histology. The nodes were carefully excised with their capsules intact, and immersed briefly in boiling water. About $6.0 \mathrm{~g}$ of lymphoid tissue pooled from several sites in the centre of each node was homogenised by means of a mechanical blender in approximately $25 \mathrm{ml}$ of sterile phosphate-buffered saline containing 100 units per $\mathrm{ml}$ each of penicillin and streptomycin. The homogenate was sown in $0.5-\mathrm{ml}$ volumes onto each of four slopes of Malt Extract Agar (Oxoid) containing 50 units per $\mathrm{ml}$ of chloramphenicol, and the cultures were incubated for 1 wk at $37^{\circ} \mathrm{C}$.

Double-diffusion method. Sera from all cattle were tested against three antigenic preparations of Aspergillus fumigatus on 1.5 per cent. borate-buffered Oxoid ion agar No. 2, $p \mathrm{H} \mathrm{8.6} \mathrm{(Murray} \mathrm{and} \mathrm{Mahgoub,} \mathrm{1968).} \mathrm{Antigen} 1$ was prepared from the culture filtrate of five strains of $A$. fumigatus cultured in Roux flasks in 3 per cent. peptone broth containing 1 per cent. glucose for $6 \mathrm{wk}$ at $28^{\circ} \mathrm{C}$. The filtrate was dialysed overnight against running tap-water, concentrated two-fold with Lyphogel (Gelman-Hawksley), filtered through Seitz disks and cellulose acetate membranes (pore size $0.45 \mu \mathrm{m}$ ) and freeze dried. Antigen 2 was prepared as above from a single strain of $A$. fumigatus. Antigen 3 was prepared from mycelium from antigen 1 culture. This was extracted in Coca's saline (see Jenkins, 1964) for 7 days, concentrated six-fold with Lyphogel, then dialysed and treated as above. The plates were kept at room temperature for 7 days and examined at intervals. After soaking in sodium citrate solution to ensure that the precipitation lines were not due to " $\mathrm{C}$-reactive protein " (Pepys, 1969), the plates were washed and stained with amido black.

\section{RESULTS}

\section{Pathology}

The following brief introduction, based on the work of Ellenberger (1911) and Carlens (1928) is given to clarify our conception of the pathogenesis of the mycotic lesions observed. Central areas of the Peyers' patches contain deep concavities or cisternae, the more superficial parts of which are lined by normal mucosa with villi, and are enclosed by rings of muscularis mucosae (fig. 1). In the deeper portions the villi and muscularis mucosae are absent, and the lymphoid tissue lies just beneath a layer of columnar epithelium. In many cisternae the basal lymphoid tissue bulges upwards, forming truncated cones covered by epithelium and surrounded by moat-like spaces (fig. 2). The conformation of these cisternae clearly renders them liable to pathological changes, should impaction of their orifices occur.

Cisternal impaction within the Peyer's patches was found in 43 animals, often in more than one intestinal site. Distension of the cisternae had occurred due to the accumulation of mucus, desquamated epithelial cells and effete leucocytes. Vegetable material was often present as well, and may have caused the impaction in many instances. Necrosis of the columnar epithelium had often led to inflammatory changes in underlying tissues. In one animal (no. 8 in the table) a profuse mycelial growth was present in the cisterna (fig. 3), consisting of branching, irregularly swollen hyphae, some containing transverse septa. Of the four animals shown in the table as possessing asteroid bodies in the Peyer's patches, three (nos. 8, 19 and 70) had distended necrotic cisternae adjacent to the lesions. The table shows that granulomata containing asteroid bodies were found only in the mesenteric nodes in a further 14 animals; often more than one node was affected. These lesions consisted of encapsulated masses of epithelioid cells infiltrated by eosinophils, with central purulent cores 


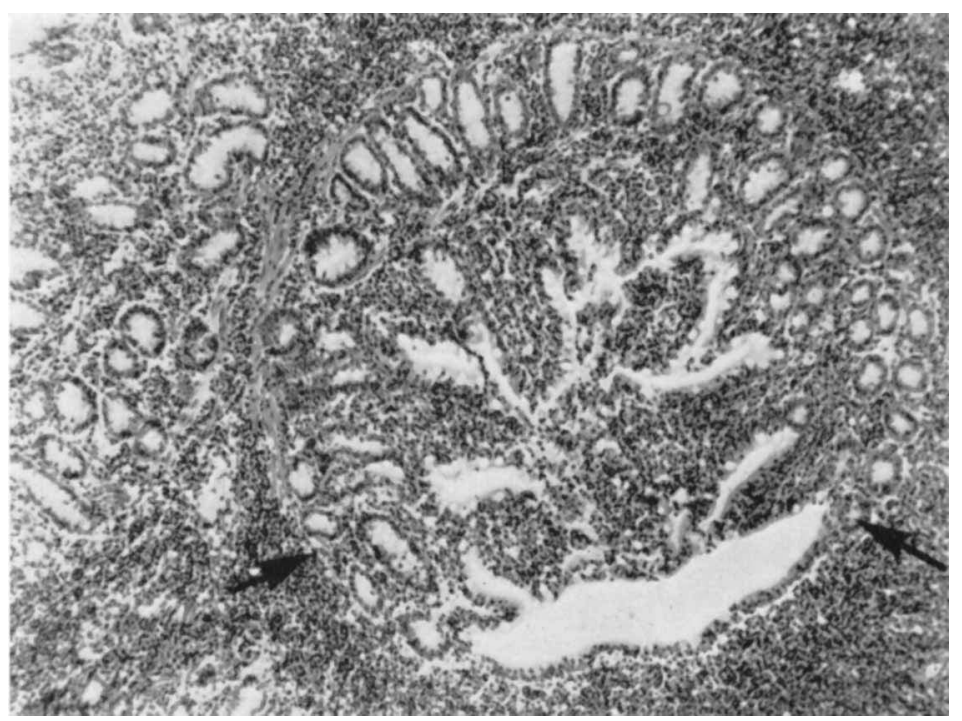

FIG. 1.-Peyer's patch cut transversely, showing cisternal orifice. The transition between superficial and deep portions (arrowed) is apparent in an area cut obliquely. Haematoxylin and eosin (HE). $\times 60$.

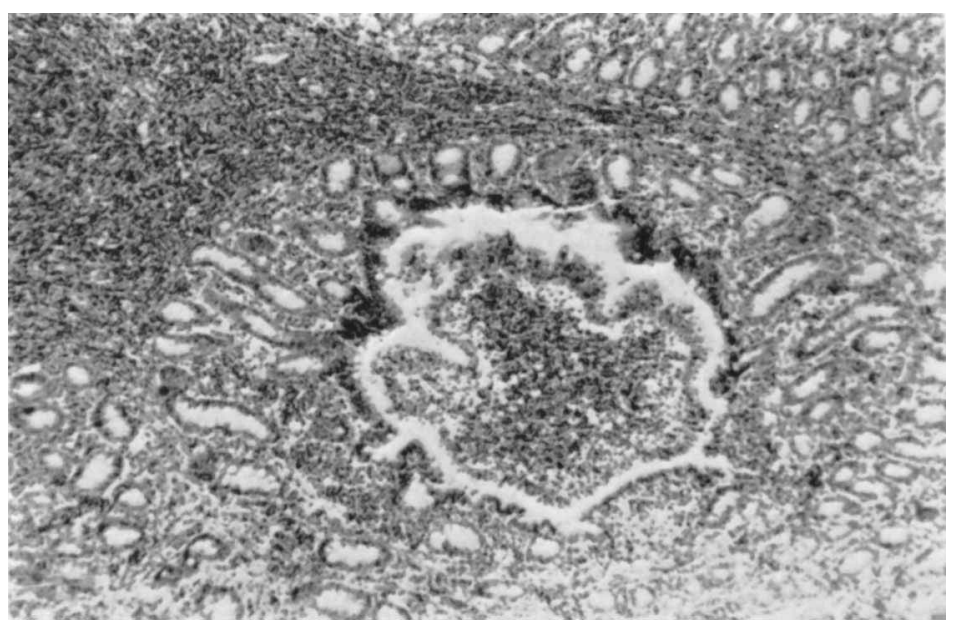

Fig. 2.-Transverse section of cisterna showing a central lymphoid papilla and encircling space. HE. $\times 60$. 
ALIMENTARY MYCOTIC LESIONS IN CATTLE

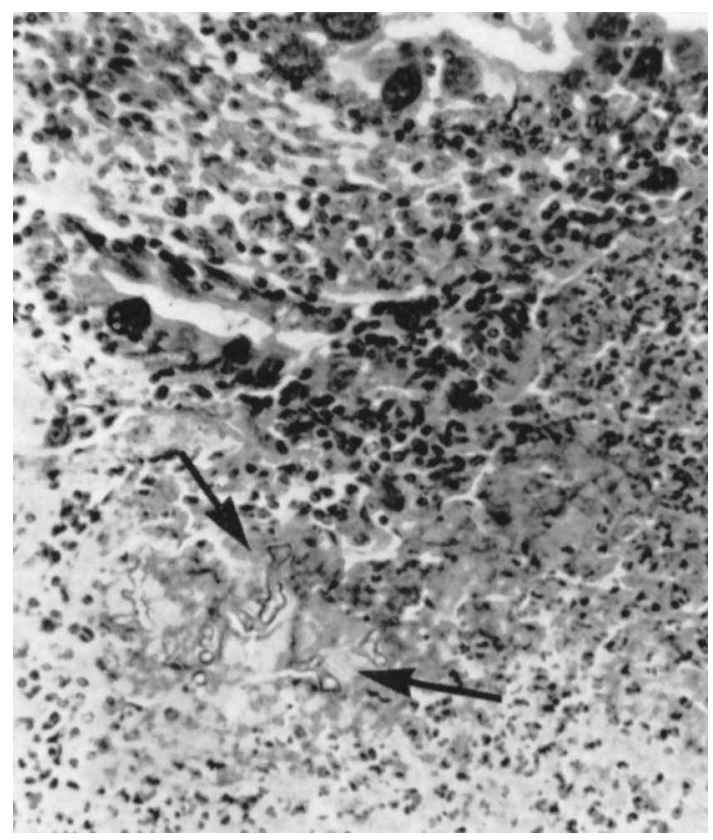

FIG. 3.-Animal no. 8: impacted and distended cisterna containing fungal mycelium (arrowed). Periodic acid-Schiff. $\times 150$.

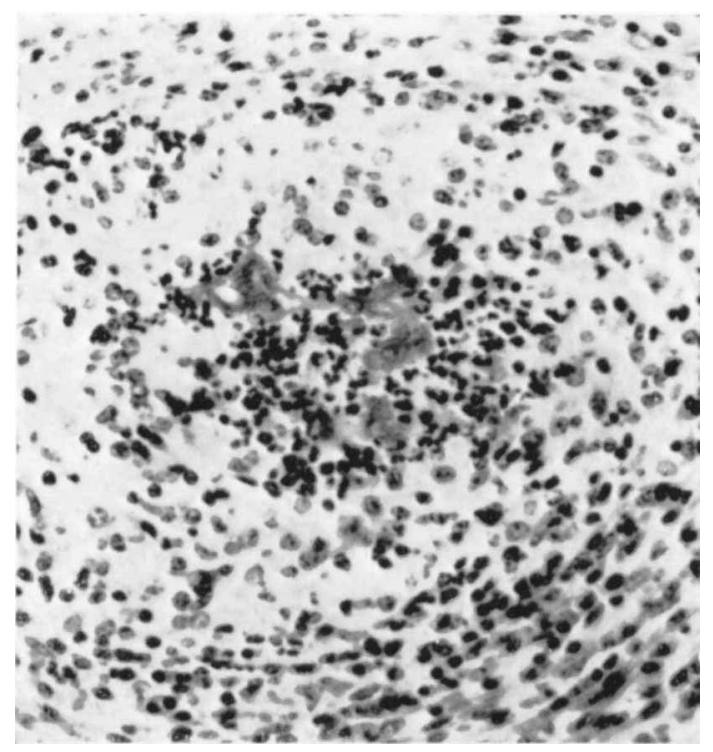

FIG. 4.-Animal no. 43: centre of mycotic granuloma, showing "asteroid body" with enclosed hypha. HE. $\times 150$. 
which enclosed the asteroid bodies. These either comprised circular masses of radiating clubs resembling rosettes, or had the morphology of hyphal fragments encrusted by eosinophilic material (fig. 4). When treated by the PAS method,

TABLE

Histological and cultural findings in 100 cattle at an abattoir

\begin{tabular}{|c|c|c|c|}
\hline $\begin{array}{l}\text { Animal } \\
\text { number }\end{array}$ & $\begin{array}{l}\text { Sites in which asteroid } \\
\text { body-containing lesions } \\
\text { were seen }\end{array}$ & $\begin{array}{l}\text { PAS-positive } \\
\text { hyphae seen } \\
\text { in lesion }\end{array}$ & $\begin{array}{l}\text { Fungal species } \\
\text { isolated from } \\
\text { mesenteric nodes }\end{array}$ \\
\hline $\begin{array}{l}40 \\
41 \\
43 \\
45 \\
48 \\
49 \\
52 \\
59 \\
69 \\
70 \\
71 \\
72 \\
74 \\
75 \\
76 \\
77 \\
78 \\
79 \\
82 \\
87 \\
88\end{array}$ & $\begin{array}{l}\text { Mesenteric node } \\
\text { Mesenteric node } \\
\text { Intestine and Peyer's patch } \\
\text { Mesenteric node } \\
\text { Peyer's patch } \\
\text { Mesenteric node } \\
\text { Mesenteric node } \\
\text { Mesenteric node } \\
\text { Mesenteric node } \\
\text { Mesenteric node } \\
\text { N } \\
\text { Mesenteric node } \\
\text { N } \\
\text { N } \\
\text { Mesenteric node } \\
\text { Mesenteric node } \\
\text { Mesenteric node } \\
\text { Peyer's patch } \\
\text { Mesenteric node } \\
\mathbf{N} \\
\mathbf{N} \\
\mathbf{N} \\
\mathbf{N} \\
\text { Mesenteric node } \\
\text { Peyer's patch } \\
\mathbf{N} \\
\mathbf{N}\end{array}$ & $\begin{array}{l} \pm \\
\pm \\
\pm \\
\pm \\
\pm \\
\pm \\
= \\
\pm \\
\pm \\
= \\
= \\
= \\
= \\
\pm \\
\pm \\
-\end{array}$ & $\begin{array}{l}\text { Scopulariopsis sp. } \mathbf{N}^{\mathrm{N}} \\
\mathbf{N} \\
\text { Aspergillus terreus } \dagger \\
\mathbf{N} \\
\text { A. terreus } \dagger \\
\text { Aspergillus candidus } \dagger \\
\mathbf{N} \\
\mathbf{N} \\
\mathbf{N} \\
\text { Aspergillus fumigatus, } \\
\text { A. terreus } \\
\mathbf{N} \\
\text { A. fumigatus } \\
\text { A. fumigatus } \\
\text { Mucor sp. } \\
\text { A. fumigatus } \\
\text { Byssochlamys sp. } \\
\text { Circinella sp. } \\
\mathrm{N} \\
\mathrm{N} \\
\text { A. fumigatus } \\
\text { A. fumigatus } \\
\text { A. fumigatus } \\
\text { A. fumigatus } \\
\text { A. fumigatus } \\
\text { A. fumigatus } \\
\text { A. fumigatus } \\
\mathrm{N} \\
\text { A. fumigatus } \\
\text { A. fumigatus } \\
\text { A. fumigatus } \\
\text { A. fumigatus }\end{array}$ \\
\hline
\end{tabular}

The 67 animal numbers missing in the series $1-100$ represent entirely negative cattle.

$\uparrow$ The culture method was that used for Mycobacterium johnei; it did not absolutely exclude the possibility of fungal contamination.

$\mathrm{N}=$ None.

the rosette forms appeared as PAS-positive tear- or ring-shaped bodies, while those morphologically resembling hyphal cell walls usually stained brilliantly. The small size of the fragments precluded identification of the fungal species, and in some animals the sections serial to the original haematoxylin-eosin preparations showed only asteroid debris on PAS treatment, being presumably cut beyond the hyphal fragments. In such cattle, therefore, only the presence of asteroid bodies is recorded. The table shows that PAS-positive hyphae were present in lesions in 11 animals. 


\section{Correlation between histological and cultural findings}

As shown in the table, granulomata containing asteroid bodies were found in histological sections from eight of the animals with numbers from 1-34. On examination of cultures made from these 34 cattle by a method designed primarily for the isolation of $M$. johnei, fungal growth was found from four animals (nos. 6, 10, 14 and 17); in only one of these four cattle had mycotic lesions been seen. The possibility of fungal contamination of these cultures could not be ruled out, and a technique considered suitable for the isolation of pathogenic fungi was used for animals no. 35-100. By means of this technique, a further 18 isolations ( 27 per cent. of samples) were made. The identities of all fungi isolated are listed in the table. Of the 66 cattle with numbers from $35-100$, ten are shown in the table as having lesions containing asteroid bodies. Of these ten cattle, six yielded fungi on cultural examination, including five which had lesions containing PAS-positive hyphae. Twelve of the cattle with numbers from 35-100 yielded fungal isolates in the absence of evidence of microscopical lesions. It was found that Aspergillus spp. predominated amongst the isolates, especially $A$. fumigatus, which was cultured from 15 animals. Lesions suggestive of mycotic infection were found in one to four animals in each of the first $6 \mathrm{mth}$ of the survey. The greatest number of fungal isolates, 11, was obtained from 19 animals (nos. 70-88) examined in June. Microscopical lesions were not detected in the 12 animals slaughtered during July and August, and cultures of their mesenteric nodes were all negative.

\section{Presence of precipitating antibodies}

Six serum samples contained precipitating antibody to A. fumigatus antigen 1. Two were from cattle with no other evidence of fungal infection, but two were from cattle (nos. 35 and 71 in the table) from which $A$. fumigatus was isolated, and which had microscopical evidence of fungal infection. The remaining two cattle (nos. 13 and 59) had microscopical lesions only. Negative results were obtained from all samples with antigens 2 and 3.

\section{DisCUSSION}

The lesions found in experimental cattle by Gilmour and Angus (1969) and Angus and Gilmour (1970) were indistinguishable from many of those in the present survey of apparently healthy cattle brought to an abattoir. Cultures were incubated at $37^{\circ} \mathrm{C}$ only, because it was considered that fungi unable to grow at that temperature were unlikely to be potential systemic pathogens, but it is possible that the isolates may not represent the full range of fungi present. Fungal growth from homogenates of mesenteric node prepared under aseptic conditions was frequently correlated with the detection of specific lesions. Granulomata contained asteroid bodies which often enclosed PAS-positive hyphal fragments. It is interesting that of the six animals shown to be positive by both a reliable culture method and by histological examination, two possessed precipitating antibody for $A$. fumigatus. 
The majority of animals had probably been housed for some time before slaughter, this being normal practice in the east of Scotland during the winter and early spring. It seems possible, therefore, that infection resulted from exposure to mouldy winter feeds or bedding. Mouldy hay is a common source of fungal spores, which may reach high concentrations in farm buildings (Lacey and Lacey, 1964). Heating occurs in bales containing more than 25 per cent. moisture, with resultant growth of thermophilic fungi and actinomycetes (Pepys, 1969). The moisture content is established at the time of baling (Austwick, 1963) and depends materially on the prevailing weather (HughJones and Austwick, 1967). There is no obvious reason why the majority of isolations of fungi were made in June, and in other months the numbers of positive animals are too low for firm conclusions. Absence of lesions or isolates from 12 cattle in July and August could be explained if spore levels encountered at pasture are less significant in terms of infection than those in buildings during winter and spring months.

It seems likely that spores trapped in impacted, distended cisternae of the Peyer's patches penetrate into nearby damaged tissues. This mode of infection seems well illustrated by animal no. 8 (see the table and fig. 3). However, the recent finding that the yeast cells of Candida albicans can pass directly from the gut to the bloodstream and urine (Krause, Matheis and Wulf, 1969) indicates that entry of fungi through the intestinal wall may also occur by other mechanisms. Many opportunistic fungi have spores ranging in size from 1-3 $\mu \mathrm{m}$ (Pepys), and these are readily phagocytosed by macrophages. Phagocytosis will destroy spores completely in some animal species; in mice for example, it disposed of an infection of Aspergillus flavus spores in 4-7 days (Sidransky and Friedman, 1959), the spores apparently being unable to germinate. Should germination of spores occur, the hyphal buds so formed cannot be phagocytosed because of their size (Frenkel, 1962), but the young hyphae become surrounded by epithelioid and giant cells; concurrently, a coating of eosinophilic material forms over the fungal cell-walls, producing the asteroid bodies seen in stained sections. In the case of Sporothrix (Sporotrichum) schenckii, this coating is actually a precipitate formed by the reaction of antigen and antibody at the cell-surface (Lurie and Still, 1969), and it is likely that the asteroid formations associated with other fungal species are similarly derived. The present study showed hyphae in the mesenteric nodes of apparently healthy cattle, and this strongly indicates that a second mechanism of immunity exerted an effect after phagocytosis had proved less than completely successful. This second type of response might lead to enhanced resistance to subsequent infections, or might even prevent reinfection altogether. However, the dispersal of macrophages carrying spores capable of germination might constitute a hazard, for example during pregnancy (Cordes, Dodd and O'Hara, 1964a).

Almost all of the fungal species isolated in the survey can be pathogenic if circumstances are favourable (Ainsworth and Austwick, 1955, 1959; Austwick and Venn, 1961; Cordes, Dodd and O'Hara, 1964 $a$ and $b$; Cordes and Shortridge, 1968; Hillman, 1969). The isolation of a Byssochlamys sp. is of interest, since such species are known to be the perfect state of Paecilomyces 
spp., normally regarded as soil saprophytes. Systemic paecilomycosis was described in a dog by Jang et al. (1971), who cited reports of infections in man, a horse and a chameleon, but the isolation of a Byssochlamys sp. from bovine tissues has not as far as we can determine been recorded previously. Lesions were not detected histologically in the single animal from which this organism was isolated and the significance of its presence in the mesenteric lymph-node is doubtful.

The isolation of Aspergillus spp. and Mucor spp. from the mesenteric lymph-nodes of healthy cattle is important in that these organisms have been shown to infect other organs, including the placenta. Experimental infection of cattle with organisms of either genus can result in the development of asteroid bodies in the placenta (Dawson, unpublished observations; Hill et al., 1971). The recent literature on mycotic abortion, reviewed by Campbell (1969), emphasises the gaps in our knowledge of pathogenesis, and there appears to be no direct evidence that the spores of fungi commonly implicated in systemic mycoses such as mycotic abortion pass directly from the gut into the circulation. Our findings show that they can penetrate to the mesenteric lymph-nodes in cattle, and that some germinate in these sites. This leads us to suggest that the bovine intestine is one portal of entry for organisms producing systemic mycoses.

\section{SUMMARY}

Histological examination of the small intestines and mesenteric lymph-nodes of 100 cattle slaughtered at an abattoir between 1 Jan. and 31 Aug. 1971 revealed granulomata containing " asteroid bodies" in 18 animals. Fungal hyphae were demonstrated in the asteroid bodies in 11 of these 18 cattle. Fungi were isolated from 18 out of 66 animals in which mesenteric nodes were examined by a reliable cultural method. The findings suggest that the intestine may be an important portal of entry in systemic fungal infections of cattle.

Special acknowledgement is due to Mr J. Norval, Edinburgh Corporation Health Department, who kindly allowed us to collect material for the survey, and to Mr Forrest, who provided facilities at Gorgie abattoir. The authors are also grateful for the technical assistance of Messrs G. U. Aitchison, W. Ramsay and D. R. Finlayson. Thanks are also due to Mr M. G. Christie, Moredun Institute, for providing incubator facilities, and to $\mathrm{Mr}$ D. G. Watson for the photomicrographs.

\section{REFERENCES}

Ainsworth, G. C., AND Austwick, P. K. C. 1955. A survey of animal mycoses. Vet. Rec., $67,88$.

Arnsworth, G. C., AND Austwick, P. K. C. 1959. Fungal diseases of animals. Commonwealth Bureau of Animal Health, Review Series no. 6.

ANGus, K. W., AND GiLmour, N. J. L. 1970. The occurrence of mycotic lesions in calves experimentally dosed with Mycobacterium avium. J. Comp. Path. Ther., 80, 187.

Austwick, P. K. C., AND VenN, J. A. J. 1961. Mycotic abortion in England and Wales 1954-1960. Proc. IVth Int. Cong. on Animal Reproduction, The Hague, vol. 3, p. 562.

Austwick, P. K. C. 1962. The presence of Aspergillus fumigatus in the lungs of dairy cows. Lab. Invest., 11, 1065. 
Austwick, P. K. C. 1963. Ecology of Aspergillus fumigatus and the pathogenic phycomycetes. In Recent progress in microbiology. Symposia held at the VIII International Congress for Microbiology, Montreal, 1962, edited by N. E. Gibbons, Toronto, p. 644.

Brotherston, J. G., Gilmour, N. J. L., AND SAmuel, J. MCA. 1961. Quantitative studies of Mycobacterium johnei in the tissues of sheep. I. Routes of infection and assay of viable M. johnei. J. Comp. Path. Ther., 71, 286.

Campbell, C. K. 1969. Mycotic abortion. Vet. Ann., 10, 129.

Carlens, O. 1928. Studien über das lymphatische Gewebe des Darmkanals bei einigen Haustieren, mit besonderer Berucksichtigung der embryonalen Entwicklung, der Mengenverhältnisse und der Altersinvolution dieses Gewebes im Dünndarm des Rindes. Z. Anat., 86, 393.

Cordes, D. O., Dod, D. C., AND O'HARA, P. J. 1964a. Bovine mycotic abortion. N.Z. Vet. J., 12, 95.

Cordes, D. O., Dodd, D. C., And O'Hara, P. J. 1964b. Acute mycotic pneumonia of cattle. N.Z. Vet.J., 12, 101.

Cordes, D. O., AND Shortridge, E. H. 1968. Systemic phycomycosis and aspergillosis of cattle. N.Z. Vet. J., 16, 65.

Davis, C. L., ANDerson, W. A., AND MCCrory, B. R. 1955. Mucormycosis in food producing animals. A report of twelve cases. J. Am. Vet. Med. Ass., 126, 261.

Ellenberger, W. 1911. Handbuch der vergleichenden mikroskopischen Anatomie der Haustiere, vol. 3, Berlin.

Frenkel, J. K. 1962. The role of corticosteroids as predisposing factors in fungal diseases. Lab. Invest., 11, 1192.

GiLmour, N. J. L., NisBet, D. I., AND Brotherston, J. G. 1965. Experimental oral infection of calves with Mycobacterium johnei. J. Comp. Path. Ther., 75, 281.

Gilmour, N. J. L., AND ANGUS, K. W. 1969. Aspergillus fumigatus in the mesenteric lymph nodes and intestinal mucosa of cattle. Br. Vet.J., 125, xiii.

GrTteR, M., AND AUSTWICK, P. K. C. 1957. The presence of fungi in abomasal ulcers of young calves: a report of seven cases. Vet. Rec., 69, 924 .

Gleiser, C. A. 1953 . Mucormycosis in animals. A report of three cases. J. Am. Vet. Med. Ass., 123, 441.

Hill, M. W. M., Whiteman, C. E., Benjamin, Maxine M., and Ball, L. 1971. Pathogenesis of experimental bovine mycotic placentitis produced by Aspergillus fumigatus. Vet. Path., 8, 175.

Hillman, R. B. 1969. Bovine mycotic placentitis in New York State. Cornell Vet., 59, 269.

Hugh-Jones, M. E., AND Ausrwick, P. K. C. 1967. Epidemiological studies in bovine mycotic abortion. I. The effect of climate on incidence. Vet. Rec., 81, 273.

Jang, S. S., Biberstein, E. L., Slauson, D. O., AND Suter, P. F. 1971. Paecilomycosis in a dog. J. Am. Vet. Med. Ass., 159, 1775.

Jenkins, P. A. 1964. Immunological studies in farmer's lung. Ph.D. Thesis. University of London.

Krause, W., Matheis, H., and Wulf, K. 1969. Fungaemia and funguria after oral administration of Candida albicans. Lancet, 1, 598.

LACEY, J., AND LACEY, MAUREEN E. 1964. Spore concentrations in the air of farm buildings. Trans. Br. Mycol. Soc., 47, 547.

LURIE, H. I., AND STILL, W. J. S. 1969. The " capsule" of Sporotrichum schenckii and the evolution of the asteroid body: a light and electron microscopic study. Sabouraudia, 7,64 .

Murray, I. G., AND Mahgoub, E. S. 1968. Further studies on the diagnosis of mycetoma by double diffusion in agar. Sabouraudia, 6, 106.

Pepys, J. 1969. Hypersensitivity disease of the lungs due to fungi and organic dusts. Monographs in allergy, vol. 4; Basel and New York, pp. 50, 70, and 97.

Sidransky, H., AND FrIEdman, L. 1959. The effect of cortisone and antibiotic agents on experimental pulmonary aspergillosis. Am. J. Path., 35, 169.

SMITH, J. M. B. 1968. Mycoses of the alimentary tract of animals. N.Z. Vet. J., 16, 89. 